\title{
Costs of Transforming Established Primary Care Practices to Patient-Centered Medical Homes (PCMHs)
}

\author{
Neil S. Fleming, PhD, Briget da Graca, JD, MS, Gerald O. Ogola, PhD, MPH, MS, \\ Steven D. Culler, PhD, Jessica Austin, MPH, Patrice McConnell, MHSA, \\ Russell McCorkle, MBA, Phil Aponte, MD, Michael Massey, MD, MS, and \\ Cliff Fullerton, MD, MS
}

Background: The patient-centered medical home (PCMH) shows promise for improving care and reducing costs. We sought to reduce the uncertainty regarding the time and cost of PCMH transformation by quantifying the direct costs of transforming $\mathbf{5 7}$ practices in a medical group to National Committee for Quality Assurance (NCQA)-recognized Level III PCMHs.

Methods: We conducted structured interviews with corporate leaders, and with physicians, practice administrators, and office managers from a representative sample of practices regarding time spent on PCMH transformation and NCQA application, and related purchases. We then developed and sent a survey to all primary care practices (practice-level response rate: initial recognition- $44.6 \%$, renewal$35.7 \%)$. Direct costs were estimated as time spent multiplied by average hourly wage for the relevant job category, plus observed expenditures.

Results: We estimated HealthTexas' corporate costs for initial NCQA recognition (2010-2012) at $\$ 1,508,503$; for renewal (2014-2016), $\$ 346,617$; the Care Coordination resource costs an additional ongoing \$390,790/year. A hypothetical 5-physician HealthTexas practice spent another estimated 239.5 hours $(\$ 10,669)$ obtaining, and 110.5 hours $(\$ 4,957)$ renewing, recognition.

Conclusion: Centralized PCMH support reduces the burden on practices; however, overall time and cost remains substantial, and should be weighed against the mixed evidence regarding PCMH's impact on quality and costs of care. (J Am Board Fam Med 2017;30:460-471.)

Keywords: Health Expenditures, Health Policy, Incentive Reimbursement, Medical Home, Patient-Centered Care, Practice Management, Primary Health Care, Surveys and Questionnaires

Primary care-particularly the aspects targeting disease prevention and management, care coordination, patient engagement, and population health management-is critical to improving health and outcomes and controlling the costs of care in the United States. ${ }^{1}$ The patient-centered medical home $(\mathrm{PCMH})$ is a care delivery model frequently

This article was externally peer reviewed

Submitted 10 February 2017; revised 23 March 2017; accepted 28 March 2017.

From the Center for Clinical Effectiveness (NSF, BdG, GOO) and STEEEP Analytics (JA), Office of the CQO, Baylor Scott \& White Health, Dallas, TX; the Robbins Institute for Health Policy \& Leadership, Baylor University, Waco (NSF, BdG); the Rollins School of Public Health, Emory University, Atlanta, GA (SDC); the HealthTexas Provider Network, Dallas (PM, RM, PA, MM); the touted as providing the structure to support this work, and in the 6 years since the Affordable Care Act authorized its testing, PCMH initiatives and recognition programs have proliferated. ${ }^{2}$ Evidence regarding the impact of the PCMH model on quality of care, health resource utilization, and outcomes has been gradually accumulating. ${ }^{3-11}$ However, little information is available regarding the

Baylor Scott \& White Quality Alliance, Dallas (MM, CF); and Baylor Scott \& White Health, Dallas (CF).

Funding: This project was funded by the Agency for Healthcare Research and Quality (grant R03 HS022621-01, principal investigator NSF).

Conflict of interest: none declared.

Corresponding author: Neil S. Fleming, PhD, 8080 North Central Expressway, Suite 500, Dallas, TX 75206 (E-mail: neil.fleming@baylorhealth.edu). 
time, effort, and costs involved. Such information is critical to primary care providers engaged in decisions about whether (or when) to commit to $\mathrm{PCMH}$ transformation so that they can anticipate the demands and allocate resources accordingly in order to ensure minimal disruption of patient care and the practice's financial health. Many primary care physicians will likely be facing this question as the Medicare Access and CHIP Reauthorization Act of 2015 comes into effect in 2017, as PCMH recognition from a national third-party program is an avenue that guarantees physicians following the Merit-Based Incentive Payment System (MIPS) pathway full credit in the Clinical Improvement Activities portion of the MIPS score. ${ }^{12}$

The few studies investigating costs associated with $\mathrm{PCMH}$ transformation have been limited to specific aspects of the PCMH model, for example, the additional staff needed ${ }^{13}$ or direct personnel costs associated with staffing the PCMH functions, ${ }^{14}$ or to specific contexts such as the Veterans Health Administration (VHA). ${ }^{15}$ One case study of 2 small, independent primary care practices that had already deployed many of the PCMH principles did report overall time and costs associated with their efforts to obtain National Committee for Quality Assurance (NCQA) recognition, estimating these at 500 hours and $\$ 46,000$, respectively, which the authors concluded would be prohibitive for most small practices. ${ }^{16}$ Another small study, looking at 3 pediatric practices and 1 family medicine practice in North Carolina, estimated the cost of successfully obtaining recognition by the NCQA as a level $3 \mathrm{PCMH}$ under the 2011 criteria at $\$ 11,453-15,977$ per full-time provider; at the practice level this would range from approximately $\$ 34,000$ for a practice with 2.5 full-time providers to $>\$ 120,000$ for a practice with 10.5 full-time providers. ${ }^{17}$ However, none of these results is generalizable to the context in which growing numbers of primary care practices deliver care: a large physician network affiliated with a hospital or integrated health care delivery system. ${ }^{18,19} \mathrm{We}$ address this gap in the evidence with data collected from a network whose practices underwent PCMH transformation in 2010 to 2012.

\section{Methods}

\section{Setting}

HealthTexas Provider Network is the fee-for-service ambulatory care provider network affiliated with Baylor Scott \& White Health, a not-for-profit health care system in north and central Texas. It includes $>250$ primary care, specialty care, and senior health centers and $>1000$ physicians in the Dallas-Fort Worth area. All HealthTexas primary care practices (except the senior health centers) implemented a common electronic health record between 2006 and 2008. ${ }^{20}$

In late 2009, HealthTexas's board of directors passed a resolution requiring all primary care practices to obtain NCQA PCMH recognition. HealthTexas created a corporate PCMH resource, appointing a director and hiring $\mathrm{PCMH}$ specialists to coordinate this effort. Other corporate resources supporting this work included (1) an informatics and disease management team, which was responsible for designing and programming the changes in the electronic health record to support PCMH model workflows and to capture the data necessary to meet the NCQA performance measurement and reporting requirements; (2) a clinical informatics team, which developed and produced those reports; (3) physician champions, who conducted the NCQA-required chart audits and educated HealthTexas physicians on the PCMH model and the workflow and documentation changes necessary to support it; and (4) the Care Coordination resource, which targets wellness, prevention, care transitions, and chronic disease management for high-risk patients.

By December 2012, HealthTexas had 57 level 3 and 3 level 2 NCQA-recognized PCMHs (2008 criteria). In May 2016, 56 of the original PCMHs had renewed (33 under the 2011 criteria and 23 under the 2014 criteria; 1 practice closed), and 14 new primary care clinics had obtained recognition (7 under the 2011 criteria, 7 under the 2014 criteria).

\section{Data Collection and Analysis}

We considered the direct costs of PCMH transformation and NCQA recognition and renewal, including wages, application fees, supplies, and infrastructure or capital purchases. Only incremental costs associated with practice transformation and obtaining or renewing recognition were considered, not ongoing practice expenses for activities that were part of daily operations before the PCMH initiative. This study was approved by the Baylor Scott \& White Research Institute institutional review board. 


\section{Practice Data Collection}

We selected a random sample of 6 HealthTexas primary care practices from the recognized PCMHs at the start of the study period, stratified by $\mathrm{PCMH}$ recognition date and practice size, plus 1 senior health center and 1 community care clinic. We invited their practice administrator, lead physician, and office manager, as well as any additional staff identified by these individuals as having been with the practice at the time of application, to participate in individual interviews. Interviews were conducted between October 2014 and October 2015 (to capture both initial PCMH transformation and renewal experiences) by a single member of the research team (BdG); interviews used a structured interview guide, and detailed notes of interviewees' responses were recorded in a standardized data collection form developed in Excel (Microsoft Corp., Redmond, WA). All interviews were conducted by telephone (for consistency across the geographic reach of the sample), except for 2 with individuals who requested a faceto-face format. The interview questions addressed participants' experience with both the initial PCMH recognition process (2008 NCQA criteria) and renewal (2011 or 2014 criteria).

A broad application of qualitative content analysis of interviewee responses, analyzing interview notes line by line to elicit themes, informed the survey design. A mixed deductive and inductive approach identified a list of themes consistent with tasks involved in the implementation of NCQA PCMH standards, as well as additional information about clinic needs for successful implementation of PCMH standards. Further analysis summarized and grouped similar themes and statements to create a list of possible answer choices in the survey. Themes and statements appearing more than twice were included as survey answer choices or served as examples. To increase the likelihood that survey respondents understood the answer choices, all survey item responses were phrased to be consistent with the perspectives of the interviewees. This approach to survey design enabled survey answer choices to consist of specific tasks that emerged from the interviewees' responses, capturing both activities directly addressed by the NCQA PCMH standards and "behind the scenes" activities facilitating the standards.
We developed and managed the survey using Qualtrics survey software (Qualtrics, Provo, UT). It was constructed as 4 blocks of questions to allow for the fact that some respondents were not involved in $\mathrm{PCMH}$ recognition or recertification at all, whereas others participated in 1 or the other, or both. An early question asked respondents to indicate their involvement at each stage, and they received only the relevant question blocks. A participant receiving all 4 blocks encountered 48 questions, which included 3 optional free-text responses, 8 Likert-scale responses, 11 multiple choice/selections from a list items, and 26 items asking for estimates of time spent. The survey was intended to take no more than 10 to 15 minutes.

The survey was administered electronically via an anonymous link. For analysis purposes, participants specified their job role and clinic name if they were involved in either the recognition or the recertification process. The link was sent via E-mail to all primary care practice administrators (including those for the practices in the random sample with whom key informant interviews were conducted) with a request that they both complete the survey and pass on the link, requesting that all physicians and staff in the primary care clinic(s) for which they were responsible also complete the survey. No incentives for participation were offered. This method of survey distribution is used frequently within HealthTexas and ensured all members of the target population received the link through their preferred E-mail address. The survey remained open for 3 weeks during January to February 2016, with weekly reminders and updates sent via the practice administrators. After the survey was closed, Qualtrics data were output to Microsoft Excel and imported to SAS 9.4 (SAS Institute, Inc., Cary, NC) for analysis.

Survey responses from the senior health centers were excluded because these practices had not implemented an electronic health record, and the paper-based record system was expected to substantially increase the time required to complete many of the PCMH transformation and recognition activities. Responses from practices joining later (those that obtained initial recognition under either the NCQA 2011 or 2014 criteria) were also excluded because of the substantial changes made in the NCQA criteria between 2008 and 2011. 


\section{Corporate Data Collection}

In May and June 2015, 2 members of the research team (BdG, NSF) jointly conducted structured interviews with key members of the HealthTexas corporate resources supporting the $\mathrm{PCMH}$ initiative. A structured interview guide was used, and detailed notes of interviewees' responses were recorded in a standardized data collection form developed in Excel. Interviewees included directors of care coordination, clinical informatics, and $\mathrm{PCMH}$; vice presidents of chronic disease, care redesign, informatics, and disease management; a PCMH physician champion; and a PCMH manager and specialist. The interview questions addressed both initial recognition and renewal.

\section{Payroll and Expense Data}

Data related to corporate expenses and payrolls were obtained from the Lawson GL (general ledger) and Payroll Systems. The HealthTexas accounting department reviews all payroll data monthly and reconciles them with the GL. The Baylor Scott \& White Health human resources department defines all job codes and is consulted when determining staffing category linkages.

The costs of additional infrastructure or capital required for $\mathrm{PCMH}$ recognition were assessed from the GL. Payments for NCQA application fees were not identified for individual practices. All payments from 2010 to 2013 were assumed to be for initial recognitions. For the period January 2014 to May 2016, 16 applications for initial recognition came from new primary care practices, in addition to the renewal fees for the original HealthTexas PCMHs. Because the NCQA fees vary by the number of physicians in the practice, we estimated the amount paid for renewal fees during this period by calculating the total number of physicians in practices with either an initial recognition or renewal date between January 2014 and May 2016, and the percentage of these within the renewing practices, and then prorated the amount paid to NCQA.

\section{Estimating Costs}

Direct costs were estimated based on (1) the time and effort for activities by job category for corporate and practice resources and (2) observed expenditures in the GL. Estimates of wages paid were based on the time individuals reported multiplied
Table 1. Practice Characteristics for the $\mathbf{5 6}$ HealthTexas Provider Network National Committee for Quality Assurance Level 3 Patient-Centered Medical Homes That Obtained Recognition under the 2008 Criteria and Remained Open Throughout Our Study Period (October 2014 to February 2016)

\begin{tabular}{lc}
\hline PCMH recognition period & \\
August 2010 to December & $14(25.0)$ \\
2011 (early adopters) & $42(75.0)$ \\
January 2012 to December & \\
2012 (midterm adopters) & \\
Practice size & $31(55.4)$ \\
Small ( $<5$ physicians) & $22(39.3)$ \\
Midsize (5-16 physicians) & $3(5.3)$ \\
Large (17-33 physicians) & \\
Practice type & $5(8.9)$ \\
Pediatric clinic & $4(7.1)$ \\
Community clinic & $3(5.4)$ \\
Senior center & $44(78.6)$ \\
Internal/family medicine & \\
\hline
\end{tabular}

Data are $\mathrm{n}(\%)$.

by the average hourly rate for that individual's job category. For corporate and individual practice employees, the average wage rate was estimated from payroll records. For physicians, an estimated mean hourly wage was calculated as reimbursement minus overhead expenses, averaged across the HealthTexas primary care physicians and divided by the standard annual number of working hours $(\mathrm{n}=$ 2080).

Time and effort for physicians and staff within the individual practices were reported in hours (reflecting the concentrated effort over a short period of time involved in an individual practice's preparation and application for $\mathrm{PCMH}$ recognition). We reported median amounts of effort (and associated costs) by job category for the different activities across the practices. The longer-term efforts of members of the HealthTexas corporate resources supporting the network-wide process were annualized to full-time equivalents, based on the duration and intensity of effort reported.

\section{Results}

Table 1 shows the characteristics of the HealthTexas primary care practices that achieved NCQA PCMH recognition. The HealthTexas corporate costs that resulted from time spent on the activities related to initial NCQA recognition are shown in Table 2; those related to renewal are listed in Table 3 . 
Table 2. Time and Activities for the HealthTexas Corporate Patient-Centered Medical Home (PCMH) Team for Initial National Committee for Quality Assurance PCMH Accreditation (2008 Criteria)

\begin{tabular}{|c|c|c|c|c|c|}
\hline Role & Activities & Time & $\begin{array}{l}\text { Annualized } \\
\text { FTE }^{*}\end{array}$ & $\begin{array}{l}\text { Mean Hourly } \\
\text { Wage }(\$)^{\dagger}\end{array}$ & $\begin{array}{c}\text { Total } \\
\text { Cost }(\$)\end{array}$ \\
\hline \multirow[t]{3}{*}{ PCMH director } & $\begin{array}{l}\text { - Assemble program structure and write } \\
\text { first application }\end{array}$ & $\begin{array}{l}0.50-0.60 \text { FTE (first } \\
6 \text { months, January } \\
\text { to June 2010) }\end{array}$ & 0.28 & 79.00 & 45,185 \\
\hline & $\begin{array}{l}\text { - Work with practice administrators } \\
\text { and operations managers to get the } \\
\text { guidelines/protocols/processes in } \\
\text { place and the documentation needed } \\
\text { for the application }\end{array}$ & $\begin{array}{l}0.10-0.15 \text { FTE (July } \\
\text { 2010-June 2012) }\end{array}$ & 0.25 & & 41,077 \\
\hline & $\begin{array}{l}\text { - Develop standard practices and } \\
\text { templates for the applications, put } \\
\text { together a handbook to guide } \\
\text { practices through the process; write } \\
\text { applications; build and categorize the } \\
\text { library of documents required for the } \\
\text { application; write guidelines and } \\
\text { protocols required by the standards, } \\
\text { shepherding them through the } \\
\text { approval process; teach leaders about } \\
\text { PCMH }\end{array}$ & $\begin{array}{l}\sim 0.40 \text { FTE (July } \\
2010 \text { to June } \\
2012)^{\ddagger}\end{array}$ & 0.80 & & 131,448 \\
\hline \multirow[t]{2}{*}{ PCMH specialists } & $\begin{array}{l}\text { - Learn about PCMHs; learn the } \\
\text { NCQA online tool through which } \\
\text { applications are submitted; upload the } \\
\text { first practice application; } \\
\text { communicate with NCQA regarding } \\
\text { inconsistencies or ambiguities in their } \\
\text { instructions }\end{array}$ & $\begin{array}{l}\text { 1.0 FTE (first } 6 \\
\text { months, January to } \\
\text { June 2010) }\end{array}$ & 0.50 & 28.38 & 29,512 \\
\hline & $\begin{array}{l}\text { - Work with practice administrators } \\
\text { and operations managers to put } \\
\text { together the documentation for the } \\
\text { practice applications; write the } \\
\text { applications }\end{array}$ & $\begin{array}{l}2 \text { FTE (July } 2010 \text { to } \\
\text { June 2012) }+ \\
\sim 0.1 \text { FTE for } 8 \\
\text { months }+0.2 \\
\text { FTE for } 4 \\
\text { months }^{\ddagger}\end{array}$ & 4.13 & & 243,968 \\
\hline \multirow[t]{6}{*}{$\begin{array}{l}\text { Physician executive } \\
\text { leader }\end{array}$} & $\begin{array}{l}\text { - Obtain board approval for } \\
\text { HealthTexas-wide PCMH endeavor; } \\
\text { get primary care physicians aligned } \\
\text { and motivated; lead the physician } \\
\text { champions; promote/hire } \\
\text { administrative leaders and staff for } \\
\text { the PCMH initiative }\end{array}$ & $\begin{array}{l}0.1-0.15 \text { FTE for } \\
12-18 \text { months }\end{array}$ & 0.17 & 146.40 & 51,386 \\
\hline & - Interpret NCQA PCMH criteria & & & & \\
\hline & $\begin{array}{l}\text { - Work with the decision support } \\
\text { group to get the reports needed for } \\
\text { PCMH accreditation }\end{array}$ & & & & \\
\hline & $\begin{array}{l}\text { - Work with physicians to write up the } \\
\text { information for the } 3 \text { target } \\
\text { conditions (diabetes, asthma, heart } \\
\text { failure) and the evidence-based } \\
\text { guidelines for those, and pull together } \\
\text { patient education for those conditions }\end{array}$ & & & & \\
\hline & $\begin{array}{l}\text { - Work with the disease management } \\
\text { group to build templates in the EMR; } \\
\text { create physician checklists for patient } \\
\text { visits involving the target conditions }\end{array}$ & & & & \\
\hline & $\begin{array}{l}\text { - Audit and review the applications } \\
\text { (especially first, which was his } \\
\text { practice, and other early ones); maybe } \\
2 \text { hours spent on this }\end{array}$ & & & & \\
\hline
\end{tabular}


Table 2. Continued

\begin{tabular}{|c|c|c|c|c|c|}
\hline Role & Activities & Time & $\begin{array}{c}\text { Annualized } \\
\text { FTE }^{*}\end{array}$ & $\begin{array}{l}\text { Mean Hourly } \\
\text { Wage }(\$)^{\dagger}\end{array}$ & $\begin{array}{l}\text { Total } \\
\text { Cost }(\$)\end{array}$ \\
\hline \multirow[t]{2}{*}{ Physician champions } & $\begin{array}{l}\text { - Engage and train primary care } \\
\text { physicians, educating them on what } \\
\text { PCMH is, what getting accreditation } \\
\text { involves, and what they would need to } \\
\text { do }\end{array}$ & $\begin{array}{l}\text { 0.6 FTE (a half day/ } \\
\text { week for each of } 6 \\
\text { MDs) for } \sim 12 \\
\text { months }\end{array}$ & 0.60 & 146.40 & 51,386 \\
\hline & $\begin{array}{l}\text { - Review the required } 36 \text { charts per } \\
\text { practice for compliance with the } \\
\text { criteria on the clinical side }\end{array}$ & $\begin{array}{l}\text { 1.0 FTE for July } 2010 \\
\text { to June } 2012(20 \mathrm{~h} / \\
\text { week for } 1 \text { physician, } \\
3-4 \mathrm{~h} / \text { week for } 5 \\
\text { physicians) }\end{array}$ & 2.00 & & 609,024 \\
\hline \multirow[t]{3}{*}{$\begin{array}{l}\text { Informatics and } \\
\text { disease } \\
\text { management }\end{array}$} & $\begin{array}{l}\text { - Coordinate changes in the EMR to } \\
\text { facilitate PCMH (add/change content, } \\
\text { change wordings, tag things so reports } \\
\text { could be created; add more structured } \\
\text { data to capture of all requirements as } \\
\text { they related to the } 3 \text { PCMH target } \\
\text { conditions); chair the clinical } \\
\text { committee reviewing all protocols for } \\
\text { the PCMH initiative }\end{array}$ & $\begin{array}{l}\text { Physician: } 0.2 \text { FTE (first } \\
6 \text { months, January to } \\
\text { June 2010) }\end{array}$ & 0.10 & 130.65 & 27,175 \\
\hline & $\begin{array}{l}\text { - Perform administrative and leadership } \\
\text { tasks }\end{array}$ & $\begin{array}{l}\text { Physician: } 0.1 \text { FTE (July } \\
2010 \text { to June 2012) }\end{array}$ & 0.20 & & 54,350 \\
\hline & - Program the changes in the EMR & $\begin{array}{l}\text { Staff: } 0.2 \text { FTE (Jan } 2010 \\
\quad \text { to June 2012) }\end{array}$ & 0.40 & 60.70 & 50,498 \\
\hline \multirow{4}{*}{$\begin{array}{l}\text { HealthTexas director } \\
\text { of clinical } \\
\text { informatics }\end{array}$} & $\begin{array}{l}\text { - Spend supervisory time related to } \\
\text { PCMH reporting work }\end{array}$ & 0.25 FTE for 12 months & 0.25 & 84.38 & 43,875 \\
\hline & $\begin{array}{l}\text { - Creating reports required to meet the } \\
\text { PCMH criteria-both creation of new } \\
\text { reports (eg, pre-visit planning), and } \\
\text { tweaking existing reports so that they } \\
\text { would include the necessary elements } \\
\text { (eg, performance reports for asthma } \\
\text { and diabetes) } \\
\text { - Data sources: EHR, HealthTexas } \\
\text { data warehouse } \\
\text { - used SQL server reporting services }\end{array}$ & $\begin{array}{l}\text { Programming time: } \\
\text { - Previsit planning: } \\
60 \text { hours } \\
\text { - Demographics: } 24 \\
\text { hours } \\
\text { - Priority conditions: } \\
60-100 \text { hours each } \\
\text { if no pre-existing } \\
\text { report } \$\end{array}$ & 0.16 & & 27,338 \\
\hline & - Produce the reports (automated) & Negligible human time & 0.00 & 0 & 0 \\
\hline & $\begin{array}{l}\text { - Answer queries practices submit to the } \\
\text { help desk regarding reports }\end{array}$ & $\begin{array}{l}\text { 1.5 FTE for all helpdesk } \\
\text { services; during } \\
\text { application periods, } \\
\sim 10 \% \text { of queries are } \\
\text { related to PCMH } \\
\text { reports }\end{array}$ & 0.15 & 24.29 & 7,579 \\
\hline \multirow[t]{2}{*}{$\begin{array}{l}\text { Care coordination } \\
\text { resource }\end{array}$} & \multirow{2}{*}{$\begin{array}{l}\text { - Identify and confirm gaps in preventive } \\
\text { and chronic disease care, and schedule } \\
\text { appointments to address these } \\
\text { Note: We chose to focus on preventive } \\
\text { services that can be billed for, ensuring } \\
\text { that the care coordination resource } \\
\text { pays for itself (under the FFS model) }\end{array}$} & $\begin{array}{l}8 \text { FTE medical } \\
\text { assistants }\end{array}$ & 8.00 & 18.75 & 312,023 \\
\hline & & 1 FTE manager" & 1.00 & 37.87 & 78,767 \\
\hline
\end{tabular}

*Number of full-time equivalents (FTEs) (eg, 1 FTE) multiplied by the number of months (eg, 24 months) over which those FTEs were sustained, divided by 12 months = the annualized FTE (eg, 2 FTEs).

${ }^{\dagger}$ The mean hourly wage included a $22 \%$ fringe rate to account for the cost of employee benefits.

${ }^{\ddagger}$ This included 3 weeks spent putting together the corporate application $(0.20 \mathrm{FTE}$ for the PCMH director [with an associated cost of $\$ 1,896$ ] + 2 FTE PCMH specialists [with an associated cost of \$6,811]). The corporate application captured 44.25 of the 100 points required for accreditation; the remaining 55.75 had to come from individual practice applications.

${ }^{\S}$ HealthTexas had existing reports for 2 of the 3 priority conditions and was able to revise these to incorporate the PCMH criteria; for the calculation of time and cost, however, we assumed creation of 3 novel reports.

"Ongoing expense.

EMR, electronic medical record; FFS, fee-for-service; NCQA, National Committee for Quality Assurance. 
We estimated that the time spent by members of the corporate resources supporting the practices' initial achievement of NCQA recognition cost $\$ 1,413,801$, plus an ongoing $\$ 390,790$ per year for care coordination. For renewal, the one-time cost of the corporate resources (other than ongoing care coordination costs) totaled $\$ 234,612$.

Of the 56 practices that achieved initial PCMH recognition under the NCQA 2008 criteria and were still operating when we conducted the survey

Table 3. Time and Activities for HealthTexas Corporate Patient-Centered Medical Home (PCMH) Team for renewal of National Committee for Quality Assurance PCMH accreditations (2011 or 2014 criteria)

\begin{tabular}{|c|c|c|c|c|c|}
\hline Role & Activities & Time & $\begin{array}{l}\text { Annualized } \\
\text { FTE* }^{*}\end{array}$ & $\begin{array}{l}\text { Mean Hourly } \\
\text { Wage }(\$)^{\dagger}\end{array}$ & $\begin{array}{c}\text { Total } \\
\text { Cost }(\$)\end{array}$ \\
\hline \multirow[t]{2}{*}{$\begin{array}{l}\text { PCMH } \\
\text { specialists }\end{array}$} & $\begin{array}{l}\text { - Work with practice administrators } \\
\text { and office managers to put } \\
\text { together the documentation for } \\
\text { the practice applications; write the } \\
\text { applications }{ }^{\ddagger}\end{array}$ & $53.3 \mathrm{~h} /$ practice $^{\ddagger}$ & 1.44 & 28.38 & 85,018 \\
\hline & $\begin{array}{l}\text { - Conduct training on } \\
\text { documentation in the EMR } \\
\text { related to new standards (mostly } \\
\text { related to replacing heart failure } \\
\text { with depression as one of the } \\
\text { priority conditions [required to } \\
\text { have } 1 \text { related to mental health]) }\end{array}$ & $1-2 \mathrm{~h} /$ practice $^{\S}$ & 0.04 & & 2,384 \\
\hline \multirow{2}{*}{$\begin{array}{l}\text { Physician } \\
\text { executive } \\
\text { leader }\end{array}$} & $\begin{array}{l}\text { - Develop mechanism to identify } \\
\text { high-risk patients }\end{array}$ & 12 hours & 0.01 & 146.40 & 1,757 \\
\hline & $\begin{array}{l}\text { - Lead development of new } \\
\text { guidelines (depression) and } \\
\text { metrics (to be built into EMR) }\end{array}$ & 12 hours & 0.01 & & 1,757 \\
\hline \multirow[t]{2}{*}{$\begin{array}{l}\text { Physician } \\
\text { champions }\end{array}$} & $\begin{array}{l}\text { - Educate primary care physicians } \\
\text { about changes under the } 2011 \\
\text { criteria }\end{array}$ & $1-2 \mathrm{~h} /$ practice $^{\S}$ & 0.04 & 146.40 & 12,298 \\
\hline & $\begin{array}{l}\text { - Perform required chart reviews } \\
\text { (under } 2011 \text { criteria, } 48 \text { patient } \\
\text { charts per practice; under } 2014 \\
\text { criteria, } 30 \text { charts per practice) }\end{array}$ & $\begin{array}{l}10 \mathrm{~min} / \mathrm{chart}(2011 \\
\text { criteria); } 15 \mathrm{~min} / \\
\text { chart }(2014 \\
\text { criteria) }\end{array}$ & 0.18 & & 55,486 \\
\hline \multirow[t]{2}{*}{$\begin{array}{l}\text { Informatics and } \\
\text { disease } \\
\text { management }\end{array}$} & $\begin{array}{l}\text { Develop mechanism to identify } \\
\text { high-risk patients; coordinate } \\
\text { changes in the EMR related to } \\
\text { the need to collect structured data } \\
\text { for new metrics (mostly around } \\
\text { depression, the new priority } \\
\text { condition) }\end{array}$ & $\begin{array}{l}\text { Physician: } 0.05-0.1 \\
\text { FTE }\end{array}$ & 0.08 & 130.65 & 20.381 \\
\hline & - Program the changes in the EMR & Staff: 0.1 FTE & 0.10 & 60.70 & 12,625 \\
\hline \multirow{4}{*}{$\begin{array}{l}\text { Health Texas } \\
\text { director of } \\
\text { clinical } \\
\text { informatics }\end{array}$} & $\begin{array}{l}\text { - Spend supervisory time related to } \\
\text { PCMH reporting work }\end{array}$ & $0.25 \mathrm{FTE}$ & 0.25 & 84.38 & 43,875 \\
\hline & $\begin{array}{l}\text { - Create reports required to meet } \\
\text { the PCMH criteria }\end{array}$ & $\begin{array}{l}\text { Programming } \\
\text { time: } \\
\text { - Depression: } 60 \\
\text { hours } \\
\text { - Audit tool: } 80 \\
\text { hours }\end{array}$ & 0.07 & & 11,813 \\
\hline & - Produce the reports (automated) & $\begin{array}{l}\text { Negligible human } \\
\text { time }\end{array}$ & 0.00 & 0 & 0 \\
\hline & $\begin{array}{l}\text { - Answer queries practices submit } \\
\text { to the help desk regarding reports }\end{array}$ & $\begin{array}{l}\text { 1.5 FTE for all } \\
\text { helpdesk } \\
\text { services; during } \\
\text { application } \\
\text { periods, } \sim 10 \% \\
\text { of queries are } \\
\text { related to } \\
\text { PCMH reports }\end{array}$ & 0.15 & 24.29 & 7,579 \\
\hline
\end{tabular}




\begin{tabular}{|c|c|c|c|c|c|}
\hline Role & Activities & Time & $\begin{array}{l}\text { Annualized } \\
\text { FTE* }^{*}\end{array}$ & $\begin{array}{l}\text { Mean Hourly } \\
\text { Wage }(\$)^{\dagger}\end{array}$ & $\begin{array}{c}\text { Total } \\
\text { Cost }(\$)\end{array}$ \\
\hline \multirow{2}{*}{$\begin{array}{l}\text { Care } \\
\text { coordination } \\
\text { resource }\end{array}$} & $\begin{array}{l}\text { Identify and confirm gaps in } \\
\text { preventive and chronic disease }\end{array}$ & $\begin{array}{l}8 \text { FTE medical } \\
\text { assistants }\end{array}$ & 8.00 & 18.75 & 312,023 \\
\hline & $\begin{array}{l}\text { care, scheduling appointments to } \\
\text { address these } \\
\text { Note: We chose to focus on } \\
\text { preventive services that can be } \\
\text { billed for, ensuring that the care } \\
\text { coordination resource pays for } \\
\text { itself under the FFS model }\end{array}$ & 1 FTE manager $\|$ & 1.00 & 37.87 & 78,767 \\
\hline
\end{tabular}

*Number of full-time equivalents (FTEs) (eg, 1 FTE) multiplied by the number of months (eg, 24 months) over which those FTEs were sustained, divided by 12 months = the annualized FTE (eg, 2 FTEs).

${ }^{\dagger}$ The mean hourly wage included a $22 \%$ fringe rate to account for the cost of employee benefits.

${ }^{\ddagger}$ Unlike the initial recognition process, HealthTexas did not complete a corporate application for the renewals; an individual renewal application was completed for each practice.

${ }^{\S}$ By May 2016, 56 PCMHs that obtained initial recognition under the 2008 National Committee for Quality Assurance criteria had renewed (33 under the 2011 criteria, 23 under the 2014 criteria).

"Ongoing expense.

EMR, electronic medical record; FFS, fee-for-service.

in early 2016, we received responses regarding the initial achievement of NCQA recognition from 25 (44.6\%) and regarding renewal from 20 (35.7\%), including 15 (26.8\%) from which we received responses regarding both. When we compared the characteristics (size, type, and PCMH recognition date) of the responding and nonresponding practices, we found a significant difference only in the PCMH recognition dates: practices in the "midterm adopter" group were overrepresented among the responding practices.

Table 4 identifies activities related to obtaining and renewing NCQA recognition on which physicians and staff within the Health Texas primary care practices spent time. Table 5 shows the median time spent on these activities, by job role, for the individuals who responded to our survey. Table 6 uses these results to estimate the total time (and the associated costs) spent by individuals in a hypothetical 5-physician primary care practice in HealthTexas, with the network average staffing of a practice administrator, an office manager, and 1.5 fulltime equivalent medical assistants per physician. We estimate that such a practice spent a combined 239.8 hours $(\$ 10,669)$ on achieving initial NCQA recognition and 110.5 hours $(\$ 4,957)$ on renewing recognition.

HealthTexas incurred the following costs for fees, hardware and software purchases, and training related to PCMH transformation and recognition:
- A 2-day conference providing education on PCMH in general and NCQA criteria and application in particular, attended by the physician executive leader, the director of PCMH, 2 physician champions, and 1 member of the informatics/disease management staff, for a total cost of $\$ 9,262$

- Three Visio licenses (\$550 each) for the PCMH corporate team, for a total cost of $\$ 1650$

- Phones, headsets, double computer screens, and a phone system to record calls and track the number and length of calls for the care coordination resource, for a total cost of $\$ 11,600$

- NCQA fees: When the HealthTexas practices applied for recognition in 2010 to 2012, the fees included $\$ 80$ for access to the survey tool to upload documents, plus a per-clinic fee of $\$ 500$ / provider for up to 8 providers. HealthTexas achieved a discount by submitting a corporate application and then filing the individual practice applications as addenda. The total amount paid for NCQA fees for the applications submitted between June 2010 and March 2013 was \$72,270. For renewals (January 2014 to June 2016), for which no corporate application was submitted, the fees amounted to $\$ 112,005$.

\section{Discussion}

HealthTexas spent $>\$ 2.5$ million on the initial transformation and recognition of 57 NCQA Level III PCMHs: 
Table 4. Numbers of Survey Respondents, by Job Role, Who Reported Being Involved in Specific Activities Related to Their Practices' Initial and Renewal Applications for National Committee for Quality Assurance Patient-Centered Medical Home Recognition (Survey Conducted January to February 2016)

\begin{tabular}{|c|c|c|c|c|c|c|c|c|}
\hline & \multicolumn{2}{|c|}{ Physician } & \multicolumn{2}{|c|}{$\begin{array}{c}\text { Practice } \\
\text { Administrator }\end{array}$} & \multicolumn{2}{|c|}{ Office Manager } & \multicolumn{2}{|c|}{ Other Personnel } \\
\hline & $\begin{array}{l}\text { Initial } \\
(\mathrm{n}=11)\end{array}$ & $\begin{array}{l}\text { Renewal } \\
(\mathrm{n}=10)\end{array}$ & $\begin{array}{l}\text { Initial } \\
(\mathrm{n}=16)\end{array}$ & $\begin{array}{l}\text { Renewal } \\
(\mathrm{n}=15)\end{array}$ & $\begin{array}{l}\text { Initial } \\
(\mathrm{n}=9)\end{array}$ & $\begin{array}{l}\text { Renewal } \\
(\mathrm{n}=15)\end{array}$ & $\begin{array}{l}\text { Initial } \\
(\mathrm{n}=16)\end{array}$ & $\begin{array}{l}\text { Renewal } \\
(\mathrm{n}=14)\end{array}$ \\
\hline $\begin{array}{l}\text { Review policies and procedures } \\
\text { related to PCMH standards }\end{array}$ & $4(36.4)$ & $3(30.0)$ & $13(81.3)$ & $5(33.3)$ & $8(88.9)$ & $11(73.3)$ & $3(18.8)$ & $2(14.3)$ \\
\hline Document for PCMH accreditation & $3(27.3)$ & $3(30.0)$ & $10(62.5)$ & $5(33.3)$ & $4(44.4)$ & $11(73.3)$ & $4(25.0)$ & $1(7.1)$ \\
\hline $\begin{array}{l}\text { Attend clinic team } \\
\text { huddles/meetings }\end{array}$ & $7(63.6)$ & $4(40.0)$ & $9(56.3)$ & $5(33.3)$ & $7(77.8)$ & $12(80.0)$ & $6(37.5)$ & $4(28.6)$ \\
\hline $\begin{array}{l}\text { Conduct or participate in EMR } \\
\text { training }\end{array}$ & $4(36.4)$ & $2(20.0)$ & $11(68.8)$ & $2(13.3)$ & $6(66.7)$ & $10(66.7)$ & $5(31.3)$ & $4(28.6)$ \\
\hline $\begin{array}{l}\text { Train staff on PCMH guidelines } \\
\text { and procedures }\end{array}$ & $2(18.2)$ & $3(30.0)$ & $10(62.5)$ & $3(20.0)$ & $7(77.8)$ & $8(53.3)$ & $1(6.3)$ & $1(7.1)$ \\
\hline $\begin{array}{l}\text { Accommodate for care management } \\
\text { related to PCMH }\end{array}$ & $7(63.6)$ & $2(20.0)$ & $11(68.8)$ & $4(26.7)$ & $5(55.6)$ & $10(66.7)$ & $5(31.3)$ & $4(28.6)$ \\
\hline $\begin{array}{l}\text { Adjust workflow to meet PCMH } \\
\text { requirements }\end{array}$ & $5(45.5)$ & $3(30.0)$ & $11(68.8)$ & $3(20.0)$ & $8(88.9)$ & $9(60.0)$ & $5(31.3)$ & $4(28.6)$ \\
\hline $\begin{array}{l}\text { Meet with members of the } \\
\text { corporate PCMH team }\end{array}$ & $1(9.1)$ & $0(0.0)$ & $10(62.5)$ & $8(53.3)$ & $5(55.6)$ & $10(66.7)$ & $0(0.0)$ & $1(7.1)$ \\
\hline $\begin{array}{l}\text { Patient tracking and registry } \\
\text { functions }\end{array}$ & $1(9.1)$ & $0(0.0)$ & $10(62.5)$ & $3(20.0)$ & $5(55.6)$ & $9(60.0)$ & $1(6.3)$ & $1(7.1)$ \\
\hline $\begin{array}{l}\text { Performance reporting and } \\
\text { improvement }\end{array}$ & $2(18.2)$ & $1(10.0)$ & $13(81.3)$ & $4(26.7)$ & $7(77.8)$ & $11(73.3)$ & $2(12.5)$ & $0(0.0)$ \\
\hline Develop/approve standing orders & $2(18.2)$ & $1(10.0)$ & $12(75.0)$ & $3(20.0)$ & $5(55.6)$ & $8(53.3)$ & $1(6.3)$ & $1(7.1)$ \\
\hline Other & $0(0.0)$ & $0(0.0)$ & $1(6.3)$ & $1(6.7)$ & $1(11.1)$ & $0(0.0)$ & $1(12.5)$ & $0(0.0)$ \\
\hline
\end{tabular}

EMR, electronic medical record; PCMH, patient-centered medical home.

$(57 \times \$ 10,669$ for practice time $)+\$ 1,413,801$

(corporate time) $+\$ 390,790$

(1-year cost for the care coordination

resource) $+\$ 94,782$ (non-time-re-

lated costs $)=\$ 2,507,506$

Because no previous studies have, to our knowledge, examined PCMH transformation and NCQA recognition in a large physician network providing central support for the process, comparison of our results with those in the literature is difficult. Compared with the \$774 million the VHA spent on implementing their version of the PCMH model in 908 primary care centers (a per-center cost of approximately $\$ 850,000),{ }^{15}$ the $\$ 2.5$ million HealthTexas expenditure (approximately $\$ 43,000$ per practice) seems inexpensive. However, the very different nature of the VHA compared with a fee-forservice physician network means such a comparison must be interpreted with great caution. For example, the VHA, as a closed system of care, was able to recoup \$596 million of its investment through reduced hospitalizations for ambulatory care-sensi- tive conditions and outpatient visits with mental health specialists ${ }^{15}$; in the HealthTexas context, such savings would accrue to third-party payers.

Similar problems arise with comparisons with other previous studies. One that did address private sector practices (albeit in smaller networks and including several operating within a federally qualified health center) in Utah and Colorado examined the direct personnel costs associated with staffing for the NCQA PCMH functions, reaching an estimate of $\$ 104,799$ per full-time primary care physician per year. ${ }^{14}$ However, they focused on the marginal costs of meeting the PCMH standards, potentially including those for functions that were already being performed within the practices, whereas we sought to identify the incremental costs incurred by HealthTexas through the PCMH transformation and recognition process.

The most directly comparable results are those reported from a case study of 2 small, independent primary care practices that had already deployed many of the principles underlying the PCMH model, ${ }^{16}$ and for the family medicine practice with 
Table 5. Total Time Reported and Associated Costs for Activities in Which Respondents Were Involved While Their Practice Was Obtaining and Renewing National Committee for Quality Assurance Recognition as a Patient-Centered Medical Home, by Job Role (Survey Conducted January to February 2016)*

\begin{tabular}{|c|c|c|c|c|c|c|c|}
\hline & \multirow[b]{2}{*}{$\begin{array}{l}\text { Mean Hourly } \\
\text { Wage }(\$)^{\dagger}\end{array}$} & \multicolumn{3}{|c|}{ Initial Recognition } & \multicolumn{3}{|c|}{ Renewal } \\
\hline & & $\mathrm{N}$ & $\begin{array}{l}\text { Time Spent } \\
\text { (Hours) }\end{array}$ & Associated Cost (\$) & $\mathrm{N}$ & $\begin{array}{l}\text { Time Spent } \\
\text { (hours) }\end{array}$ & Associated Cost $(\$)$ \\
\hline Physician & 151.48 & 8 & $7.5(4.5-18.0)$ & $\$ 1136(\$ 682-2727)$ & 8 & $3.5(2.0-27.5)$ & $\$ 530(\$ 303-4136)$ \\
\hline Practice administrator & 48.54 & 11 & $23.0(18.0-33.0)$ & $\$ 1117(\$ 874-1602)$ & 11 & $11.0(50-24.0)$ & $\$ 534(\$ 243-1165)$ \\
\hline Office manager & 30.81 & 9 & $48.0(29.0-96.0)$ & $\$ 1,479(\$ 893-2957)$ & 11 & $22(15.0-35.0)$ & $\$ 678(\$ 462-1078)$ \\
\hline \multicolumn{8}{|l|}{ Other personnel } \\
\hline $\begin{array}{l}\text { Clinical coordinator/ } \\
\text { supervisor }\end{array}$ & 41.47 & 1 & $120(\mathrm{n} / \mathrm{a})$ & $\$ 4,976(\mathrm{n} / \mathrm{a})$ & 1 & $110.0(\mathrm{n} / \mathrm{a})$ & $\$ 4561(\mathrm{n} / \mathrm{a})$ \\
\hline Medical assistant & 18.24 & 4 & $17.5(5.5-28.0)$ & $\$ 319(\$ 100-511)$ & 2 & $8.0(\mathrm{n} / \mathrm{a})$ & $\$ 146(n / a)$ \\
\hline $\begin{array}{l}\text { Physician office } \\
\text { representative }\end{array}$ & 16.81 & 1 & $0(\mathrm{n} / \mathrm{a})$ & $\$ 0(\mathrm{n} / \mathrm{a})$ & 1 & $12.0(\mathrm{n} / \mathrm{a})$ & $\$ 202$ (n/a) \\
\hline Social worker & 35.82 & 1 & $10.0(\mathrm{n} / \mathrm{a})$ & $\$ 358(\mathrm{n} / \mathrm{a})$ & 1 & $15.0(\mathrm{n} / \mathrm{a})$ & $\$ 537(\mathrm{n} / \mathrm{a})$ \\
\hline
\end{tabular}

Data are median (interquartile range) unless otherwise indicated. The interquartile range was not reported when $<4$ responses were received ("n/a").

*Three survey responses received from 2 senior health centers were not included because these practices did not use the electronic medical record.

${ }^{\dagger}$ The mean hourly wage included a fringe rate to account for employee benefits and was based on 2012 levels, because that was the year with the greatest patient-centered medical home transformation activity.

Table 6. Time and Associated Costs Related to Patient-Centered Medical Home Recognition and Renewal for a Hypothetical 5-Physician Practice within HealthTexas (Based on Survey Data Collected January to February 2016)

\begin{tabular}{|c|c|c|c|c|c|c|c|c|c|c|}
\hline & \multirow{3}{*}{$\begin{array}{l}\text { Mean Hourly } \\
\text { Wage }(\$)^{*}\end{array}$} & \multirow{3}{*}{$\mathrm{N}$} & \multicolumn{4}{|c|}{ Initial Recognition } & \multicolumn{4}{|c|}{ Renewal } \\
\hline & & & \multicolumn{2}{|c|}{ Time Spent (hours) ${ }^{\dagger}$} & \multicolumn{2}{|c|}{ Associated Cost $(\$)^{\dagger}$} & \multicolumn{2}{|c|}{ Time Spent (hours) $^{\dagger}$} & \multicolumn{2}{|c|}{ Associated Cost $(\$)^{\dagger}$} \\
\hline & & & Individual & Total & Individual & Total & Individual & Total & Individual & Total \\
\hline Physician & 151.48 & 5 & 7.5 & 37.5 & 1,136 & 5,680 & 3.5 & 17.5 & 530 & 2,651 \\
\hline Practice administrator & 48.54 & 1 & 23.0 & 23.0 & 1,117 & 1,117 & 11.0 & 11.0 & 534 & 534 \\
\hline Office manager & 30.81 & 1 & 48.0 & 48.0 & 1,479 & 1,479 & 22.0 & 22.0 & 678 & 678 \\
\hline Medical assistant & 18.24 & 7.5 & 17.5 & 131.3 & 319 & 2,394 & 8.0 & 60.0 & 146 & 1,094 \\
\hline Total costs & - & - & - & 239.8 & - & 10,669 & - & 110.5 & - & 4,957 \\
\hline
\end{tabular}

*The mean hourly wage included a fringe rate, to account for employee benefits, and was based on 2012 levels, as that was the year with the greatest patient-centered medical home transformation activity.

${ }^{\dagger}$ Estimated based on the medians reported in Table 5.

4 full-time providers that was included in the North Carolina study (although the latter applied under 2011 NCQA criteria, which differed from the 2008 criteria the HealthTexas practices initially applied under). ${ }^{17}$ The 2 -practice case study estimated that (with support staff at a salary of approximately $\$ 30 / \mathrm{h}$ to manage the documentation required for the NCQA application, and hiring a part-time nurse care manager to assist with population health and outreach), such a practice could expect to spend 500 hours and $\$ 46,000$ on the process of obtaining NCQA recognition. ${ }^{16}$ This estimate is approximately 4 times the cost and double the number of hours we estimated from the practice side $(\$ 10,669$ associated with 239.8 hours across the physicians and personnel in a hypothetical 5-physician practice) within HealthTexas, demonstrating the benefit to the practices of centralized support. The family medicine practice with 4 full-time providers in North Carolina had an even higher estimated cost at approximately $\$ 64,000 .{ }^{17}$ However, if the cost estimate from the 2-practice case study is compared with the full cost incurred by HealthTexas, the savings diminish substantially: $57 \times \$ 46,000=\$ 2,622,000$ (for practices applying independently) versus the $\$ 2,507,506 \mathrm{cal}-$ culated just above. It should also be noted, though, that the comparison to the $\$ 64,000$ per practice 
estimate provides a more convincing argument in favor of centralized support $(57 \times \$ 64,000=$ $\$ 3,648,000)$.

Limitations to be considered in interpreting our results include our estimations of cost based on time estimates provided by the individuals involved in $\mathrm{PCMH}$ transformation, recognition, and renewal, rather than contemporary recording of the time spent on each activity. The exploratory and retrospective observational nature of this studycombined with the practical difficulties of having all personnel and end users involved record their time separately in various categories-made the latter approach impossible. We also cannot rule out the possibility of response bias on our practice survey. We received responses from $35 \%$ to $45 \%$ of practices included in the analysis (depending on whether initial recognition or renewal was being considered). While the only significant difference we found between these practices that did respond and those that did not was an overrepresentation of midterm adopters among the former, it is possible that our results do not capture the typical practice's experience; for example, the overrepresentation of midterm adopters likely means that we have underestimated to some extent the time and cost to practices, as early adopters would be expected to spend more time on transformation tasks, not having had other practices' previous experience to draw on. Second, while our results fill the current void in information regarding the costs of PCMH transformation, recognition, and renewal for the growing numbers of practices in centralized networks similar to HealthTexas, they inevitably have limited applicability for independent practices without access to such shared resources. Finally, the question of the extent to which practices were "transformed" through the PCMH recognition process, as opposed to documenting practices, procedures, and resources that were already in place, fell beyond the scope of our study, as did the question of whether obtaining $\mathrm{PCMH}$ recognition is a valid proxy for having meaningfully implemented the PCMH model. ${ }^{16,21}$

These are important questions that future studies should address. Not only could they help ensure that the standards applied in PCMH recognition programs truly represent implementation of the PCMH model, but they could refine our results regarding the cost half of the value question, so that practices falling at both ends of the spectrum ranging from "need to fully transform to implement the PCMH model" to "have essentially implemented the PCMH model and merely need to provide the documentation necessary to obtain formal recognition" have a good sense of the time and cost those efforts are likely to incur. This could help practices at the former end allocate the necessary resources to the endeavor (assuming the PCMH model is shown to be effective in improving patient care, outcomes, and resource use) and those at the latter end weigh the costs of obtaining formal recognition against the "per member per month" payments or performance incentives it might qualify them for from payers and accountable care organizations.

As the popularity of the PCMH model continues to grow, ${ }^{2}$ the question is whether a business case can be made for the health care delivery system; that is, is investment in PCMH transformation justified by the combination of improved quality of care/better patient outcomes and costs savings through reduced hospital and emergency department visits? Currently, the evidence for quality improvement and cost saving with PCMH implementation remains mixed. ${ }^{3-11,15}$ Furthermore, business cases for quality improvements are complex, with savings not necessarily accruing to the stakeholders who invested in the quality improvement initiatives. ${ }^{22}$ As such, any financial return on investment from PCMH transformation and recognition needs to be tracked carefully to ensure the investing providers are adequately reimbursed and incentivized. A recent microsimulation model estimating the changes in practice net revenue under 3 possible PCMH funding initiatives (increased fee-for-service payments, traditional feefor-service with additional per-member-per-month payments, or traditional fee-for-service with permember-per-month and pay-for-performance payments) showed that the latter 2 offer potential financial benefits to practices but do not create incentives for practices to expand services beyond the minimum requirement for $\mathrm{PCMH}$ funding. ${ }^{23}$ Other reimbursement structures or incentive mechanisms therefore need to be considered. As the Medicare Access and CHIP Reauthorization Act of 2015 comes into effect, the credit awarded for the Clinical Improvement Activities portion of the MIPS score and the associated impact on Medicare reimbursement will also need to be evaluated in order to determine what incentives it creates for 
primary care practices to invest in and sustain $\mathrm{PCMH}$ transformation and recognition.

The authors thank all members of the HealthTexas corporate PCMH team, as well as the physicians, practice administrators, office managers, medical assistants, and other members of staff in the HealthTexas primary care clinics who gave generously of their time and knowledge to help assemble the data presented in this article.

To see this article online, please go to: http://jabfm.org/content/ 30/4/460.full.

\section{References}

1. Abrams MK, Nuzum R, Zezza MA, Ryan J, Kiszla J, Guterman S. The Affordable Care Act's payment and delivery system reforms: a progress report at five years. New York: Commonwealth Fund; 2015. Available from: http://www.commonwealthfund.org/ publications/issue-briefs/2015/may/aca-payment-anddelivery-system-reforms-at-5-years. Accessed June 12, 2017.

2. Edwards ST, Bitton A, Hong J, Landon BE. Patient-centered medical home initiatives expanded in 2009-13: providers, patients, and payment incentives increased. Health Aff (Millwood) 2014;33: 1823-31.

3. Rosenthal MB, Friedberg MW, Singer SJ, Eastman D, Li Z, Schneider EC. Effect of a multipayer patient-centered medical home on health care utilization and quality: the Rhode Island chronic care sustainability initiative pilot program. JAMA Intern Med 2013;173:1907-13.

4. Fifield J, Forrest DD, Martin-Peele M, et al. A randomized, controlled trial of implementing the patient-centered medical home model in solo and small practices. J Gen Intern Med 2013;28:770-7.

5. Harbrecht MG, Latts LM. Colorado's patient-centered medical home pilot met numerous obstacles, yet saw results such as reduced hospital admissions. Health Aff (Millwood) 2012;31:2010-7.

6. Raskas RS, Latts LM, Hummel JR, Wenners D, Levine H, Nussbaum SR. Early results show WellPoint's patient-centered medical home pilots have met some goals for costs, utilization, and quality. Health Aff (Millwood) 2012;31:2002-9.

7. Friedberg MW, Schneider EC, Rosenthal MB, Volpp KG, Werner RM. Association between participation in a multipayer medical home intervention and changes in quality, utilization, and costs of care. JAMA 2014;311:815-25.

8. Nelson KM, Helfrich C, Sun H, et al. Implementation of the patient-centered medical home in the Veterans Health Administration: associations with patient satisfaction, quality of care, staff burnout, and hospital and emergency department use. JAMA Intern Med 2014;174:1350-8.
9. Yoon J, Chow A, Rubenstein LV. Impact of medical home implementation through evidence-based quality improvement on utilization and costs. Med Care 2016;54:118-25.

10. Friedberg MW, Rosenthal MB, Werner RM, Volpp KG, Schneider EC. Effects of a medical home and shared savings intervention on quality and utilization of care. JAMA Intern Med 2015;175:1362-8.

11. Neal J, Chawla R, Colombo CM, Snyder RL, Nigam S. Medical homes: cost effects of utilization by chronically ill patients. Am J Manag Care 2015; 21:e51-61.

12. "Payment for physicians' services," Social Security Act 42 USC 1395w-4, \$1848(q)(5)(C)(i).

13. Patel MS, Arron MJ, Sinsky TA, et al. Estimating the staffing infrastructure for a patient-centered medical home. Am J Manag Care 2013;19:509-16.

14. Magill MK, Ehrenberger D, Scammon DL, et al. The cost of sustaining a patient-centered medical home: experience from 2 states. Ann Fam Med 2015; 13:429-35.

15. Hebert PL, Liu CF, Wong ES, et al. Patient-centered medical home initiative produced modest economic results for Veterans Health Administration, 2010-12. Health Aff (Millwood) 2014;33:980-7.

16. Ho L, Antonucci J. The dissenter's viewpoint: there has to be a better way to measure a medical home. Ann Fam Med 2015;13:269-72.

17. Halladay JR, Mottus K, Reiter K, et al. The cost to successfully apply for level 3 medical home recognition. J Am Board Fam Med 2016;29:69-77.

18. Bishop TF, Shortell SM, Ramsay PP, Copeland KR, Casalino LP. Trends in hospital ownership of physician practices and the effect on processes to improve quality. Am J Manag Care 2016;22:172-6.

19. Kirchhoff S. Physician practices: background, organization, and market consolidation. Congressional Research Service, January 2, 2013. Available from: https://www.fas.org/sgp/crs/misc/R42880.pdf. Accessed May 16, 2016.

20. Fleming NS, Culler SD, McCorkle R, Becker ER, Ballard DJ. The financial and nonfinancial costs of implementing electronic health records in primary care practices. Health Aff (Millwood) 2011;30:481-9.

21. Miller WL. Patient-centered medical home (PCMH) recognition: a time for promoting innovation, not measuring standards. J Am Board Fam 2014;27: 309-11.

22. Swensen SJ, Dilling JA, Mc Carty PM, Bolton JW, Harper CM Jr. The business case for health-care quality improvement. J Patient Saf 2013;9:44-52.

23. Basu S, Phillips RS, Song Z, Landon BE, Bitton A. Effects of new funding models for patient-centered medical homes on primary care practice finances and services: results of a microsimulation model. Ann Fam Med 2016;14:404-14. 